\title{
Thermovenabulum ferriorganovorum gen. nov., sp. nov., a novel thermophilic, anaerobic, endospore-forming bacterium
}

Institute of Microbiology, Russian Academy of Sciences, Prospect 60-letiya Oktyabrya 7/2, 117811

Moscow, Russia

\author{
D. G. Zavarzina, T. P. Tourova, B. B. Kuznetsov, \\ E. A. Bonch-Osmolovskaya and A. I. Slobodkin
}

Author for correspondence: Alexander Slobodkin. Tel: +795 135 4458. Fax: +7 951356530 . e-mail: slobodkin@inmi.da.ru

Keywords: Fe(III) reduction, thermophiles, endospores

\section{INTRODUCTION}

Thermophilic bacteria attract considerable attention from researchers because of their biotechnological potential and the evolutionary traits of these microorganisms. A large number of species belonging to the domain Bacteria are able to reduce various inorganic compounds including ferric iron, one of the most abundant elements on Earth (Lovley, 1991, 1995; Nealson \& Saffarini, 1994; Slobodkin et al., 1999a; Straub et al., 2001). The capacity for Fe(III) reduction is known among thermophilic bacteria with different taxonomic affiliations (Boone et al., 1995; Greene et

Published online ahead of print on 27 May 2002 as DOI 10.1099/ ijs.0.02214-0.

Abbreviation: AQDS, 9,10-anthraquinone 2,6-disulfonate.

The GenBank/EMBL/DDBJ accession number for the $16 \mathrm{~S}$ rDNA sequence of strain Z- $9801^{\top}$ is AY033493. al., 1997; Slobodkin et al., 1997, 1999b, c; Vargas et al., 1998; Kieft et al., 1999).

Thermophilic endospore-forming anaerobes have so far been found only within the Bacillus/Clostridium division of the Bacteria, where they are grouped into several genera (Collins et al., 1994). Spore-forming thermophiles have been isolated from a wide range of natural and man-made ecosystems (Lowe et al., 1993) and are probably the earliest colonizers of newly formed thermal environments by virtue of the high heat resistance of their endospores (Slobodkin et al., 1999b).

In this paper, we report the isolation of a thermophilic, anaerobic, endospore-forming bacterium, strain Z$9801^{\mathrm{T}}$. This organism was isolated during a search for $\mathrm{Fe}(\mathrm{III})$-reducing micro-organisms able to utilize molecular hydrogen as an electron donor for iron reduction. Our isolation attempts, conducted using a medium with a low concentration of yeast extract, 
have led to the isolation of a bacterium with a fermentative type of metabolism. While growth of strain Z-9801 ${ }^{\mathrm{T}}$ was obligately dependent on the presence of $\mathrm{H}_{2}$ and $\mathrm{Fe}$ (III) at low concentrations of yeast extract, $\mathrm{H}_{2}$ was not utilized for $\mathrm{Fe}(\mathrm{III})$ reduction as a sole electron donor. Strain Z-9801 ${ }^{\mathrm{T}}$ reduced Fe(III) with organic substances as electron donors; however, $\mathrm{Fe}$ (III) did not stimulate its growth. Based on its phenotypic and phylogenetic characteristics, strain Z$9801^{\mathrm{T}}$ is described as the type species of a new genus as Thermovenabulum ferriorganovorum gen. nov., sp. nov.

\section{METHODS}

Environmental samples. Samples of sediments and water were collected in September 1997 from the 'Zhelezistyi' (Ferrous) hydrothermal source in the Uzon caldera on the Kamchatka peninsula. This source is an opening, 5-7 cm in diameter, that emits hot water and gas bubbles, mostly composed of $\mathrm{CO}_{2}$. It is located on the bottom of shallow hot spring and surrounded by ochre deposits, rich in Fe(III), $30-40 \mathrm{~cm}$ in diameter and $5-10 \mathrm{~cm}$ deep. The temperature at the sampling site was $63{ }^{\circ} \mathrm{C}$ and the $\mathrm{pH}$ was $6 \cdot 8-7 \cdot 0$.

Media and cultivation. A basal medium used for enrichment and cultivation of $\mathrm{Fe}$ (III)-reducing bacteria was prepared anaerobically by boiling and cooling it under a $\mathrm{H}_{2} / \mathrm{CO}_{2}$ $(80: 20, \mathrm{v} / \mathrm{v})$ gas phase. The basal medium contained $\left(1^{-1}\right.$ distilled water): $0.33 \mathrm{~g} \mathrm{KH}_{2} \mathrm{PO}_{4}, 0.33 \mathrm{~g} \mathrm{NH}_{4} \mathrm{Cl}, 0.33 \mathrm{~g} \mathrm{KCl}$, $0 \cdot 33 \mathrm{~g} \mathrm{MgCl}_{2} \cdot 6 \mathrm{H}_{2} \mathrm{O}, 0 \cdot 33 \mathrm{~g} \mathrm{CaCl}_{2} .2 \mathrm{H}_{2} \mathrm{O}, 0 \cdot 70 \mathrm{~g} \mathrm{NaHCO}_{3}$, $0 \cdot 20 \mathrm{~g}$ yeast extract (Difco), $10 \mathrm{ml}$ vitamin solution (Wolin et al., 1963) and $1 \mathrm{ml}$ trace element solution (Slobodkin et al., 1997). No reducing agent was added to the medium. $\mathrm{Fe}(\mathrm{III})$ was provided in the form of amorphous $\mathrm{Fe}(\mathrm{III})$ oxide at $90 \mathrm{mmol} \mathrm{Fe(III)} \mathrm{1}^{-1}$ medium. The amorphous $\mathrm{Fe}(\mathrm{III})$ oxide was synthesized by titrating a solution of $\mathrm{FeCl}_{3}$ with $10 \%(\mathrm{w} / \mathrm{v}) \mathrm{NaOH}$ to $\mathrm{pH} 9.0$. The $\mathrm{pH}$ of the autoclaved medium measured at $60^{\circ} \mathrm{C}$ was $6 \cdot 8-7 \cdot 0$. The medium used for isolation of a pure culture had the same composition as a basal medium except that amorphous Fe(III) oxide was omitted and 9,10-anthraquinone 2,6-disulfonate (AQDS) $(20 \mathrm{mM})$ was added to the medium as an electron acceptor.

Enrichments and pure cultures were grown in 60-ml serum bottles with rubber stoppers and metal caps containing $10 \mathrm{ml}$ medium under an atmosphere of $\mathrm{H}_{2} / \mathrm{CO}_{2}(80: 20$, $\mathrm{v} / \mathrm{v}$ ). All transfers and sampling of cultures were performed with syringes and needles. The medium was heat-sterilized at $135^{\circ} \mathrm{C}$ for $30 \mathrm{~min}$. All incubations were at $65^{\circ} \mathrm{C}$ unless otherwise noted.

Physiological studies. Growth of bacteria in medium containing amorphous Fe(III) oxide or other insoluble compounds was determined by direct counting with a phasecontrast microscope and a counting chamber. In media with soluble components, growth was determined by counting and by measuring the increase in optical density at $600 \mathrm{~nm}$ (Spekol 10; Carl Zeiss Jena).

The ability of the organism to grow on different substrates was determined in basal medium in which the gas phase of $\mathrm{H}_{2} / \mathrm{CO}_{2}$ was replaced by a gas phase of $\mathrm{N}_{2} / \mathrm{CO}_{2}(80: 20, \mathrm{v} / \mathrm{v})$ and autoclaved or filter-sterilized substrates were added to the medium, both in the presence and absence of amorphous $\mathrm{Fe}(\mathrm{III})$ oxide. When $\mathrm{Fe}$ (III) was omitted, the medium was pre-reduced with $\mathrm{Na}_{2} \mathrm{~S} .9 \mathrm{H}_{2} \mathrm{O}\left(0 \cdot 5 \mathrm{~g} \mathrm{l}^{-1}\right)$. The cultures were incubated for 2 weeks and the ability to utilize a particular substrate was judged from culture growth and $\mathrm{Fe}(\mathrm{II})$ accumulation. Medium in which the energy source had been omitted was used as a control.

The ability of the isolated strain to use various electron acceptors was studied in the basal medium, without amorphous $\mathrm{Fe}(\mathrm{III})$ oxide, in two variants: with $\mathrm{H}_{2}$ and yeast extract [atmosphere of $\mathrm{H}_{2} / \mathrm{CO}_{2}(80: 20, \mathrm{v} / \mathrm{v}), 0 \cdot 2 \mathrm{~g}$ yeast extract ${ }^{-1}$ ] and with beef extract $\left[3.0 \mathrm{~g} \mathrm{l}^{-1}\right.$, atmosphere of $\mathrm{N}_{2} / \mathrm{CO}_{2}$ $(80: 20, \mathrm{v} / \mathrm{v})]$ as electron donors. The soluble electron acceptors were added from autoclaved stock solutions; $\mathrm{MnO}_{2}$ and elemental sulfur were added to the medium before sterilization and these media were then autoclaved at $109^{\circ} \mathrm{C}$ for $1 \mathrm{~h} . \mathrm{MnO}_{2}$ was prepared by the method of Lovley \& Phillips (1988). The medium was pre-reduced with $\mathrm{Na}_{2} \mathrm{~S} .9 \mathrm{H}_{2} \mathrm{O}\left(0.5 \mathrm{~g} \mathrm{l}^{-1}\right)$ in the experiments with sulfate, sulfite, thiosulfate, elemental sulfur and fumarate. No reducing agent was present in media containing $\mathrm{O}_{2}, \mathrm{MnO}_{2}$ or AQDS. In nitrate-amended experiments, $\mathrm{NH}_{4} \mathrm{Cl}$ was omitted from the basal medium and sodium nitrate $(20 \mathrm{mM})$ was provided as a potential electron acceptor; both reduced and reducing-agent-free media were used. Cultures grown in prereduced basal medium with beef extract without any electron acceptor were used as inocula $(5 \% \mathrm{v} / \mathrm{v})$. The use of electron acceptors was judged from culture growth (for all acceptors), sulfide production (for sulfate, sulfite, thiosulfate and elemental sulfur), change of visible colour of the medium (for AQDS), accumulation of $\mathrm{Mn}$ (II) (for $\mathrm{MnO}_{2}$ ) and from the production of ammonium from nitrate.

Temperature, $\mathrm{pH}$ and $\mathrm{NaCl}$ concentration ranges for growth and susceptibility to antibiotics were determined under an atmosphere of $\mathrm{N}_{2} / \mathrm{CO}_{2}(80: 20, \mathrm{v} / \mathrm{v})$ in modified basal medium in which amorphous $\mathrm{Fe}$ (III) oxide was omitted and beef extract $\left(3 \mathrm{~g}^{-1}\right)$ and fumarate $(20 \mathrm{mM})$ were added. The medium was pre-reduced with $\mathrm{Na}_{2} \mathrm{~S} .9 \mathrm{H}_{2} \mathrm{O}\left(0.5 \mathrm{~g} \mathrm{l}^{-1}\right)$. The $\mathrm{pH}$ range for growth was determined at $60^{\circ} \mathrm{C}$. The $\mathrm{pH}$ was adjusted with sterile stock solutions of $\mathrm{HCl}(6 \mathrm{M})$ or $\mathrm{NaOH}$ $(10 \%)$ and measured at $60^{\circ} \mathrm{C}$ with a model PHM $82 \mathrm{pH}$ meter (Radiometer) equipped with a temperature probe and calibrated at $60^{\circ} \mathrm{C}$.

Microscopy. Routine examinations and cell counting were performed under a phase-contrast ZETOPAN Reichert optical anoptral microscope. Phase-contrast micrographs of bacteria were taken using agar-coated slides (Pfennig \& Wagner, 1986). Transmission electron microscopy was performed with a model JEM-100 electron microscope (JEOL) as described previously (Bonch-Osmolovskaya et al., 1990).

Analytical techniques. Fe(III) reduction was monitored by measuring the accumulation of $\mathrm{Fe}(\mathrm{II})$ over time. $\mathrm{Fe}(\mathrm{II})$ was measured by adding a $0.5 \mathrm{ml}$ sample from the culture to $5 \mathrm{ml}$ $0.6 \mathrm{M} \mathrm{HCl}$. After $24 \mathrm{~h}$ of extraction, $\mathrm{HCl}$-soluble $\mathrm{Fe}(\mathrm{II})$ was determined with 2,2'-dipyridyl (Balashova \& Zavarzin, 1980). Mn(II) was analysed by atomic absorption spectrophotometry after $\mathrm{HCl}$ extraction (Lovley \& Phillips, 1988). Ammonium was analysed with Nessler's reagent. Determination of short-chain organic acids, alcohols and gaseous products of metabolism was performed by GC (Slobodkin \& Bonch-Osmolovskaya, 1994). Sulfide was determined by a colorimetric method, as described previously (Slobodkin \& Bonch-Osmolovskaya, 1994).

DNA characteristics. DNA was extracted and purified by the method of Marmur (1961). Its base composition was determined from the melting point according to Marmur \& Doty (1962).

$16 \mathrm{~S}$ rRNA sequence studies. The $16 \mathrm{~S}$ rRNA gene was 
selectively amplified from genomic DNA by PCR and sequenced as described previously (Slobodkin et al., 1999b). The 16S rDNA sequence was aligned with a representative set of 16S rRNA sequences obtained from the Ribosomal Database Project (Maidak et al., 2000) or from recent GenBank releases by using CLUSTAL software (Higgins \& Sharp, 1988). Positions that had not been sequenced in one or more reference organisms were omitted from the analysis. Pairwise evolutionary distances were computed by using the correction of Jukes \& Cantor (1969). The unrooted phylogenetic trees were constructed by the neighbour-joining method using the programs of the TREECON package (Van de Peer \& De Wachter, 1994), by the maximum-likelihood method using the PUZzLE program (Strimmer \& von Haeseler, 1996) and by the maximum-parsimony method using the program DNAPARS of the PHYLIP package (Felsenstein, 1989) with bootstrap analysis of 100 trees.

\section{RESULTS AND DISCUSSION}

\section{Enrichment and isolation}

A sample of sediment/water collected from a hydrothermal source surrounded with ochre deposits in the Uzon caldera on the Kamchatka peninsula was used for enrichment of thermophilic, dissimilatory $\mathrm{Fe}(\mathrm{III})$-reducing micro-organisms. Basal anaerobic medium, in which molecular hydrogen and $0.2 \mathrm{~g}$ yeast extract $1^{-1}$ were potential electron donors and amorphous $\mathrm{Fe}$ (III) oxide was provided as an electron acceptor, was inoculated with $10 \%(\mathrm{w} / \mathrm{v})$ of the sample and incubated at $60{ }^{\circ} \mathrm{C}$ in the dark. After $72-96 \mathrm{~h}$ of cultivation, non-magnetic, brown, amorphous Fe(III) oxide was converted to a black, solid material of less volume, which was strongly attracted to a magnet and contained a significant amount of $\mathrm{Fe}(\mathrm{II})$. After three
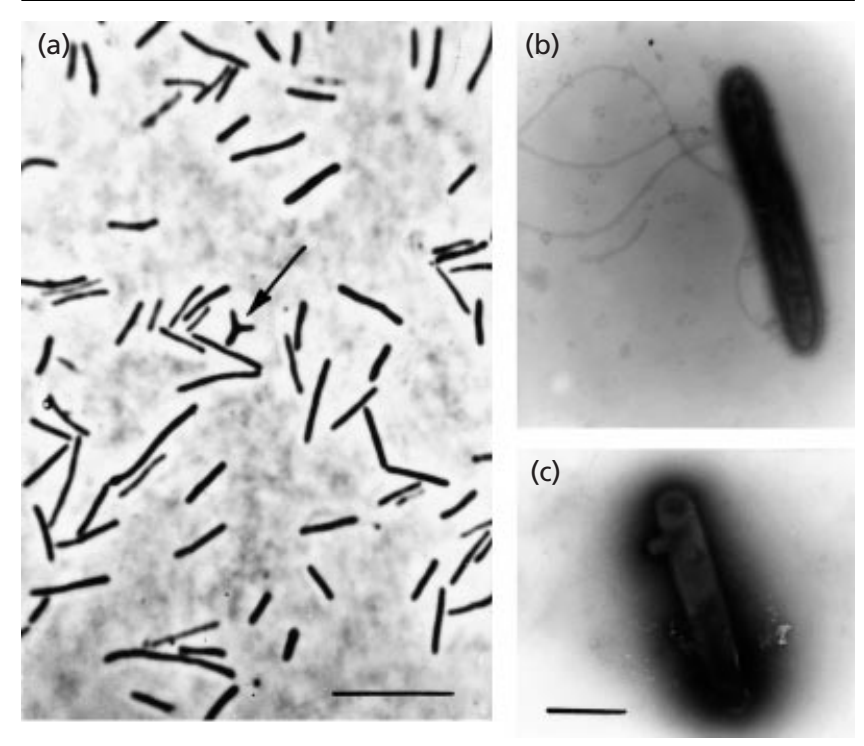

Fig. 1. Cell morphology of strain $Z-9801^{\top}$ grown in basal medium with molecular hydrogen, yeast extract $\left(0.2 \mathrm{~g} \mathrm{I}^{-1}\right)$ and AQDS. (a) Phase-contrast micrograph. Arrow indicates branched cell. Bar, $10 \mu \mathrm{m}$. (b) Electron micrograph of negatively stained cell with peritrichous flagella. (c) Electron micrograph of cell with protrusion (negative staining). Bar, $1 \mu \mathrm{m}$.

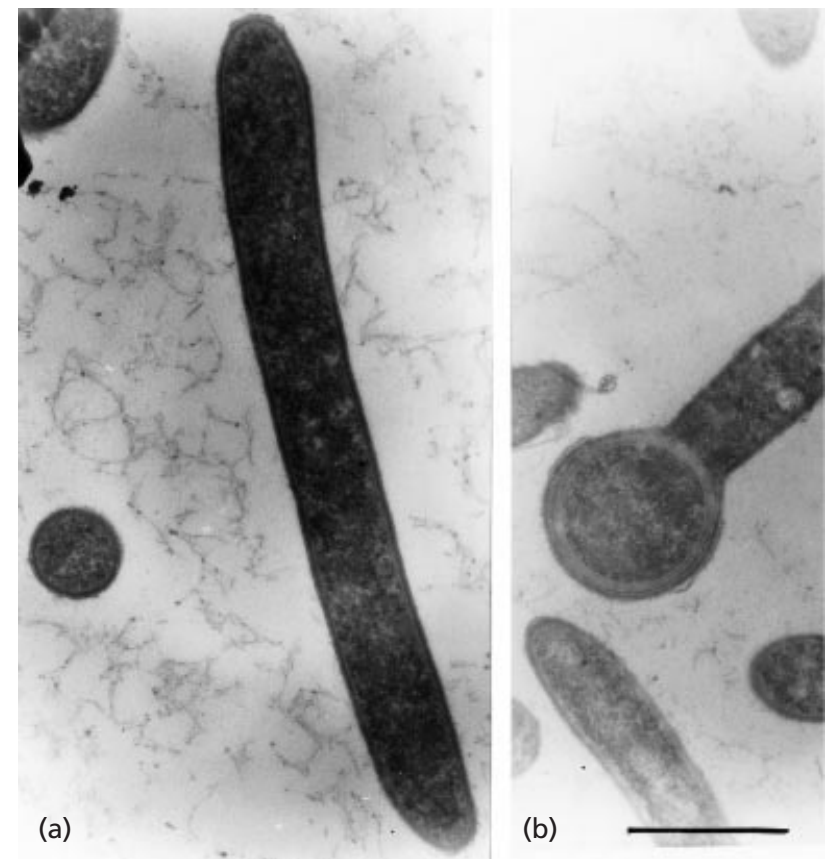

Fig. 2. Ultrathin sections of strain $Z-9801^{\top}$ showing cell-wall layers of a vegetative cell (a) and a sporulating cell (b). Bar, $1 \mu \mathrm{m}$.

successive $5 \%(\mathrm{w} / \mathrm{v})$ transfers, the enrichment was serially diluted repeatedly to extinction in the basal medium in which Fe(III) oxide was replaced by AQDS. The highest dilution that was positive for AQDS reduction $\left(10^{-6}\right)$ was serially diluted to extinction in roll tubes (Hungate, 1969) with 1.5\% Bacto agar in the basal medium with AQDS. Single colonies were removed and subcultured in liquid basal medium with amorphous $\mathrm{Fe}(\mathrm{III})$ oxide. After repeating the procedure of isolation and subculturing of single colonies, the culture was considered to be pure and was designated strain $\mathrm{Z}-9801^{\mathrm{T}}$.

\section{Colony and cell morphology}

In agar roll-tube cultures, colonies appeared after 24-48 h. The colonies were lens-shaped, $0 \cdot 1-0 \cdot 2 \mathrm{~mm}$ in diameter and white. Vegetative cells of strain Z-9801 ${ }^{\mathrm{T}}$ were straight, sometimes branched rods, $0 \cdot 5-$ $0.6 \mu \mathrm{m}$ in diameter and $1 \cdot 5-7 \cdot 0 \mu \mathrm{m}$ in length (Fig. 1a, b). Protrusions of cell envelope and cytoplasm, $0 \cdot 1-0 \cdot 3 \mu \mathrm{m}$ in length, were observed on some cells (Fig. 1c). Cells occurred singly or in short chains, were peritrichously flagellated and exhibited a slight tumbling motility. Strain Z-9801 ${ }^{\mathrm{T}}$ formed round, refractile endospores in terminally swollen sporangia. Maximum sporulation was observed in liquid medium with beef extract and fumarate: up to $15 \%$ of the cells sporulated during the late exponential phase. The cultures survived a $90 \mathrm{~min}$ exposure to $121{ }^{\circ} \mathrm{C}$, confirming that the spores were heat resistant. Ultrathin sectioning of strain Z-980 ${ }^{\mathrm{T}}$ revealed a distinct peptidoglycan layer in the cell wall (Fig. 2). 


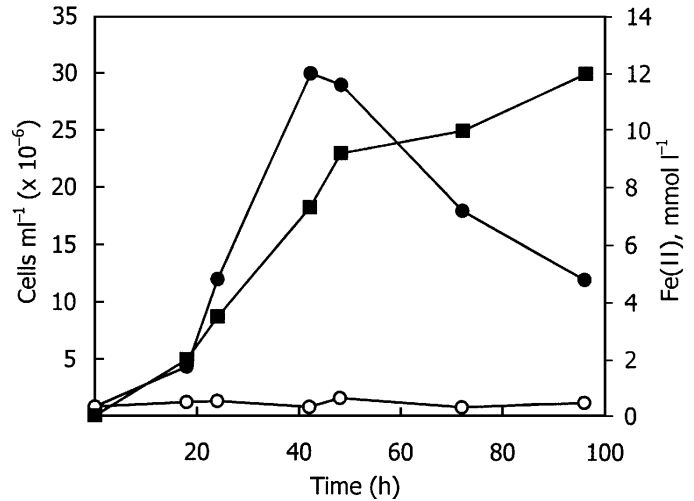

Fig. 3. Growth of and Fe(II) production by strain $Z-9801^{\top}$ with molecular hydrogen and yeast extract $\left(0.2 \mathrm{~g} \mathrm{I}^{-1}\right)$ as potential electron donors with or without amorphous Fe(III) oxide as an electron acceptor. Growth in the presence $(\mathbf{0})$ and absence $(\bigcirc)$ of $\mathrm{Fe}(\mathrm{III})$ and $\mathrm{Fe}(\mathrm{II})$ production ( $\boldsymbol{\square}$ ) are shown.

\section{Physiological characteristics}

The temperature range for growth of strain Z-9801 ${ }^{\mathrm{T}}$ was $45-76{ }^{\circ} \mathrm{C}$, with an optimum at $63-65^{\circ} \mathrm{C}$. No growth was detected at 78 or $43^{\circ} \mathrm{C}$ after 3 weeks of incubation. The strain grew at $\mathrm{pH} 4 \cdot 8-8 \cdot 2$, with an optimum at 6.7-6.9. No growth was detected at $\mathrm{pH} 4 \cdot 6$ or $8 \cdot 4$. Growth of Z-9801 ${ }^{\mathrm{T}}$ was observed at $\mathrm{NaCl}$ concentrations ranging from 0 to $3.5 \%(\mathrm{w} / \mathrm{v})$, with no growth evident at $4.0 \%(\mathrm{w} / \mathrm{v})$.

The substrates utilized by strain $\mathrm{Z}-9801^{\mathrm{T}}$ in the presence, as well as in the absence, of $\mathrm{Fe}$ (III) included peptone $\left(10 \mathrm{~g}^{-1}\right)$, yeast extract $\left(10 \mathrm{~g} \mathrm{l}^{-1}\right)$, beef extract $\left(10 \mathrm{~g}^{-1}\right)$, Casamino acids $\left(10 \mathrm{~g}^{-1}\right)$, starch $\left(10 \mathrm{~g} \mathrm{l}^{-1}\right)$ and pyruvate $(20 \mathrm{mM})$. Melibiose $(25 \mathrm{mM})$, sucrose (25 $\mathrm{mM})$, fructose $(25 \mathrm{mM})$, maltose $(25 \mathrm{mM})$, xylose $(25 \mathrm{mM})$ and ribose $(25 \mathrm{mM})$ were utilized in the absence of $\mathrm{Fe}$ (III). $\mathrm{Fe}$ (III) was chemically reduced by carbohydrates in sterile controls; the test for carbohydrate utilization in the presence of $\mathrm{Fe}(\mathrm{III})$ is therefore equivocal. Strain Z-9801 ${ }^{\mathrm{T}}$ grew and reduced $\mathrm{Fe}(\mathrm{III})$ in medium with molecular hydrogen and yeast extract $\left(0 \cdot 2 \mathrm{~g} \mathrm{l}^{-1}\right)$ (Fig. 3). The consumption of $\mathrm{H}_{2}$ $(100,10$ or $5 \%, \mathrm{v} / \mathrm{v}$, initial concentration) was not observed. However, strain Z-9801 ${ }^{\mathrm{T}}$ did not grow when $\mathrm{Fe}$ (III) was omitted or $\mathrm{H}_{2}$ was replaced by $\mathrm{N}_{2}$, indicating that both $\mathrm{Fe}$ (III) and $\mathrm{H}_{2}$ were essential for growth under these conditions. When the cultivation medium was additionally supplemented with beef extract $\left(3 \mathrm{~g}^{-1}\right)$, strain Z-9801 ${ }^{\mathrm{T}}$ grew relatively better (up to $4 \cdot 5-5 \cdot 0 \times 10^{7}$ cells $\mathrm{ml}^{-1}$ ) and utilized molecular hydrogen $\left[2 \cdot 05 \pm 0 \cdot 18 \mathrm{mmol} \mathrm{H}_{2} \mathrm{l}^{-1}\right.$ culture (mean \pm standard deviation for five cultures)]. Without Fe(III), consumption of $\mathrm{H}_{2}$ was not observed. Strain Z-9801 ${ }^{\mathrm{T}}$ did not grow without yeast extract; at least $0 \cdot 1$ g yeast extract $1^{-1}$ was required for sustainable growth. Strain Z-9801 ${ }^{\mathrm{T}}$ did not use formate $(20 \mathrm{mM})$, acetate $(20 \mathrm{mM})$, lactate $(20 \mathrm{mM})$, methanol $(20 \mathrm{mM})$, ethanol $(20 \mathrm{mM})$, glycerol $(20 \mathrm{mM})$, propionate $(20 \mathrm{mM})$, fumarate $(20 \mathrm{mM})$, glucose $(25 \mathrm{mM})$, mannose
(25 mM), galactose $(25 \mathrm{mM})$, cellobiose $(25 \mathrm{mM}), \mathrm{L}-$ arabinose $(25 \mathrm{mM})$ or glycogen $\left(10 \mathrm{~g} \mathrm{l}^{-1}\right)$, with or without $\mathrm{Fe}(\mathrm{III})$. The fermentation products from melibiose were ethanol, acetate, $\mathrm{H}_{2}$ and $\mathrm{CO}_{2}$.

Strain Z-9801 ${ }^{\mathrm{T}}$ reduced amorphous $\mathrm{Fe}(\mathrm{III})$ oxide (90 mM), Fe(III) citrate (20 mM), AQDS (20 mM), fumarate $(20 \mathrm{mM})$, sulfite $(2 \mathrm{mM})$, thiosulfate $(20 \mathrm{mM})$, elemental sulfur $(150 \mathrm{mM})$, nitrate $(20 \mathrm{mM})$ and $\mathrm{MnO}_{2}(20 \mathrm{mM})$. The product of amorphous $\mathrm{Fe}$ (III) oxide reduction was a black magnetic precipitate. Sulfite, thiosulfate and elemental sulfur were reduced to hydrogen sulfide. Nitrate was reduced to ammonium. Reduction of $\mathrm{MnO}_{2}$ resulted in the formation of a whitish precipitate composed of the $\mathrm{Mn}(\mathrm{II})$ state. Strain Z-9801 ${ }^{\mathrm{T}}$ did not reduce sulfate $(20 \mathrm{mM}), \mathrm{Fe}(\mathrm{III})$ EDTA $(15 \mathrm{mM})$ or $\mathrm{Fe}(\mathrm{III})$ nitrilotriacetate $(20 \mathrm{mM})$ and was not capable of growth with $\mathrm{O}_{2}(2 \%, v / v$, in the gas phase $)$. None of the electron acceptors utilized, except fumarate, stimulated growth of strain Z-9801 ${ }^{\mathrm{T}}$. Fe(III) stimulated growth of strain $\mathrm{Z}-9801^{\mathrm{T}}$ only in medium with molecular hydrogen and $0 \cdot 2 \mathrm{~g}$ yeast extract $1^{-1}$.

Chloramphenicol, neomycin, polymyxin B, kanamycin and streptomycin inhibited growth completely at concentrations of $100 \mu \mathrm{g} \mathrm{ml}^{-1}$ medium. Penicillin at $100 \mu \mathrm{g} \mathrm{ml}^{-1}$ did not inhibit growth.

\section{DNA characteristics and phylogenetic analysis}

The $\mathrm{G}+\mathrm{C}$ content of the genomic DNA of strain Z$9801^{\mathrm{T}}$ was $36 \mathrm{~mol} \%\left(T_{\mathrm{m}}\right)$. We determined an almost complete 16S rDNA sequence (1464 nucleotides) for strain Z-9801 ${ }^{\mathrm{T}}$, corresponding to positions 8-1489 of the Escherichia coli numbering. According to initial phylogenetic analysis by BLAST, the highest level of sequence similarity was found to species of the genus Thermoanaerobacter of the low-G + C Gram-positive subdivision of the Bacteria; however, the sequence identity did not exceed $89 \%$. Several phylogenetic trees were constructed by changing the selection of reference organisms and regions of alignment uncertainty resulting from the presence of long inserts in 16S rDNA of some members of the Bacillus/ Clostridium group (Rainey et al., 1993; Slobodkin et al., 1999b) were omitted from the sequence analysis. A final comparison of 1165 nucleotides of the $16 \mathrm{~S}$ rDNA sequence of strain Z-9801 ${ }^{\mathrm{T}}$ was made with the 39 closest reference bacterial strains, mostly of the Syntrophomonas/Thermoanaerobacter group, and used for the reconstruction of a phylogenetic tree and calculation of sequence similarity. The levels of sequence similarity of strain Z-9801 ${ }^{\mathrm{T}}$ were almost equal to all reference strains used in the analysis $(84 \cdot 4-88 \cdot 5 \%)$. Strain Z-9801 ${ }^{\mathrm{T}}$ was not clustered with any genus of the Bacillus/Clostridium group in the phylogenetic tree constructing by the neighbourjoining method (Fig. 4). The trees constructed from the maximum-likelihood and maximum-parsimony algorithms had the same topology (data not shown). The $\mathrm{G}+\mathrm{C}$ content of the $16 \mathrm{~S}$ rDNA of strain Z-9801 ${ }^{\mathrm{T}}$ 


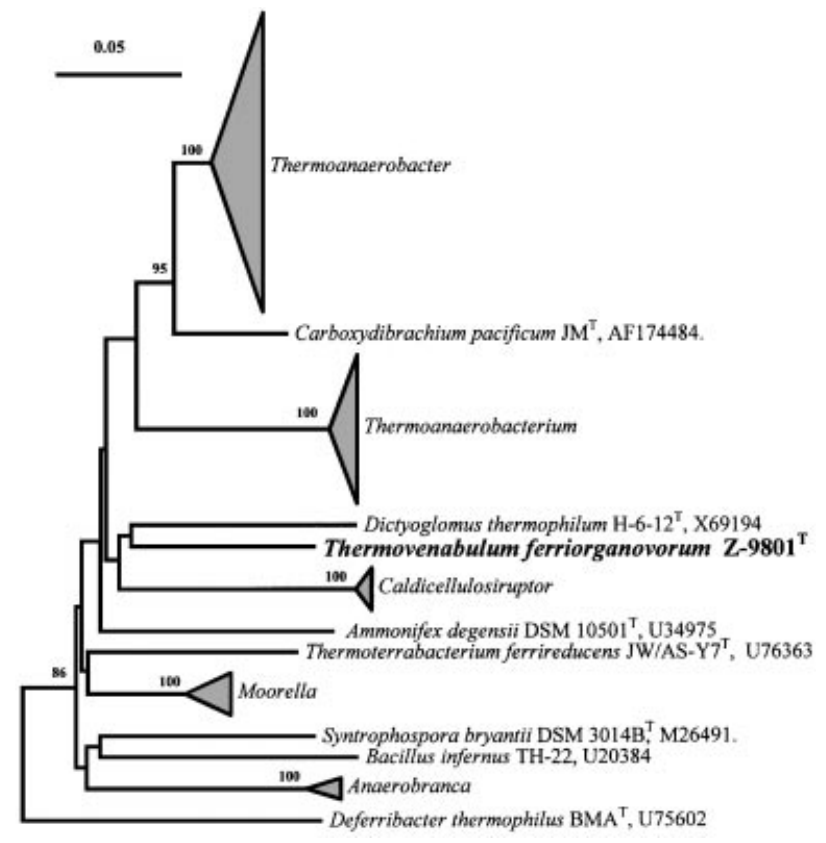

Fig. 4. Phylogenetic tree showing the position of Thermovenabulum ferriorganovorum $Z-9801^{\top}$. Bar, 0.05 expected changes per sequence position. Bootstrap values (expressed as percentages of 100 replications) are shown at branch points; values greater than $80 \%$ were considered significant. Triangles represent multifurcations containing the following sequences: Thermoanaerobacter thermohydrosulfuricus DSM 567 ${ }^{\top}$ (L09161); Thermoanaerobacter sulfurophilus L-64 ${ }^{\top}$ (Y16940); Thermoanaerobacter wiegelii Rt8.B1 ${ }^{\top}$ (X92513); Thermoanaerobacter acetoethylicus ATCC 33265 ${ }^{\top}$ (L09163); Thermoanaerobacter kivui DSM 2030 ${ }^{\top}$ (L09160); Thermoanaerobacter brockii subsp. brockii DSM 1457 ${ }^{\top}$ (L09165); Thermoanaerobacter mathranii $\mathrm{A}^{\top}{ }^{\top}$ (Y11279); Thermoanaerobacter thermocopriae JT3-3 ${ }^{\top}$ (L09167); Thermoanaerobacter ethanolicus JW 200 (L09162); Thermoanaerobacter brockii subsp. lactiethylicus SEBR 5268 ${ }^{\top}$ (U14330); Thermoanaerobacter siderophilus SR4 ${ }^{\top}$ (AF120479); Thermoanaerobacterium thermosulfurigenes E100-69 ${ }^{\top}$ (L09161); Thermoanaerobacterium aotearoense JW/SL-NZ613 ${ }^{\top}$ (X93359); Thermoanaerobacterium saccharolyticum DSM $7060^{\top}$ (L09169); Thermoanaerobacterium xylanolyticum DSM 7097 ${ }^{\top}$ (L09172); Thermoanaerobacterium thermosaccharolyticum ATCC 7956 ${ }^{\top}$ (M59119); Caldicellulosiruptor owensensis $\mathrm{OL}^{\top}$ (U80596); Caldicellulosiruptor kristjanssonii DSM $12137^{\top}$ (AJ004811); Caldicellulosiruptor lactoaceticus DSM $9545^{\top}$ (X82842); Caldicellulosiruptor saccharolyticus DSM 8903 ${ }^{\top}$ (AF130258); Moorella thermoautotrophica JW 701/5 (X58354); Moorella glycerini DSM 11254 ${ }^{\top}$ (U82327); Moorella thermoacetica DSM 521 ${ }^{\top}$ (X58352); Anaerobranca horikoshii JW/ YL-138 ${ }^{\top}$ (U21809); Anaerobranca gottschalkii DSM $13577^{\top}$ (AF203703).

$(59 \cdot 1 \mathrm{~mol} \%)$ fell into the range typical for other thermophilic prokaryotes. Transversion analysis (Woese et al., 1991) did not affect the position of the strain in the phylogenetic tree.

The thermophilic, anaerobic, endospore-forming bacteria are currently placed into the genera Clostridium, Desulfotomaculum, Thermoanaerobacter, Thermoanaerobacterium, Caloramator, Moorella, Thermacetogenium and Anoxybacillus (Wiegel, 1986; Lee et al.,
1993; Collins et al., 1994; Hattori et al., 2000; Pikuta et al., 2000). The results of $16 \mathrm{~S}$ rDNA sequence analysis did not allow to us to assign strain $\mathrm{Z}-9801^{\mathrm{T}}$ to any of these genera. Besides that, the unique features of strain Z-9801 $1^{\mathrm{T}}$ are the formation of protrusions of the cell envelope and branched cells, properties that have not been reported so far for other thermophilic, spore-forming bacteria. On the basis of these findings, we propose that strain $\mathrm{Z}-9801^{\mathrm{T}}$ should be placed in a new genus as Thermovenabulum ferriorganovorum gen. nov., sp. nov.

\section{Description of Thermovenabulum gen. nov.}

Thermovenabulum (Ther.mo.ve.na'bul.um. Gr. adj. thermos hot; L. neut. n. venabulum a hunting spear; N.L. neut. n. Thermovenabulum hot, hunting spearshaped cell, referring to the branched cell morphology).

Rod-shaped, Gram-type positive, endospore-forming (eu)bacteria. Form branched cells and protrusions of cell envelope. Anaerobic and thermophilic. Neutrophilic. Grow organotrophically on a number of fermentable substrates. Reduce $\mathrm{Fe}(\mathrm{III}), \mathrm{Mn}(\mathrm{IV})$, nitrate, sulfite, thiosulfate, elemental sulfur and fumarate. The type species is Thermovenabulum ferriorganovorum.

\section{Description of Thermovenabulum ferriorganovorum sp. nov.}

Thermovenabulum ferriorganovorum (fer.ri.or.ga.no. vo'rum. L. n. ferrum iron; N.L. n. organum organic compound; L. v. voro to eat, consume; N.L. adj. ferriorganovorum using iron and organic compounds).

Cells are straight, sometimes branched rods, 0.5 $0.6 \mu \mathrm{m}$ in diameter and 1.5-7.0 $\mu \mathrm{m}$ in length, forming round, refractile, heat-resistant endospores in terminally swollen sporangia. Cells occur singly or in short chains and exhibit slight tumbling motility due to peritrichous flagellation. The temperature range for growth is $45-76^{\circ} \mathrm{C}$, with an optimum at $63-65^{\circ} \mathrm{C}$. The $\mathrm{pH}$ range for growth is $4 \cdot 8-8 \cdot 2$, with an optimum at 6.7-6.9. Growth occurs in $\mathrm{NaCl}$ concentrations of $0-3 \cdot 5 \%(\mathrm{w} / \mathrm{v})$. Anaerobic. Substrates utilized include peptone, yeast extract, beef extract, Casamino acids, starch, pyruvate, melibiose, sucrose, fructose, maltose, xylose and ribose. Utilizes molecular hydrogen in the presence of $\mathrm{Fe}$ (III) and an organic electron donor. No growth occurs with formate, acetate, propionate, lactate, methanol, ethanol, glycerol, glucose, mannose, galactose, arabinose, cellobiose or glycogen. The fermentation products from melibiose are ethanol, acetate, $\mathrm{H}_{2}$ and $\mathrm{CO}_{2}$. Reduces amorphous $\mathrm{Fe}(\mathrm{III})$ oxide, $\mathrm{Fe}$ (III) citrate, AQDS, fumarate, nitrate, sulfite, thiosulfate, elemental sulfur and $\mathrm{MnO}_{2}$. Nitrate is reduced to ammonium. Sulfite, thiosulfate and elemental sulfur are reduced to hydrogen sulfide. None of the electron acceptors utilized, except fumarate, stimulates growth. Does not reduce sulfate and is 
incapable of growth with $\mathrm{O}_{2}$. Growth is inhibited by chloramphenicol, neomycin, polymyxin $\mathrm{B}$, kanamycin and streptomycin but not by penicillin. The $\mathrm{G}+\mathrm{C}$ content of DNA is $36 \mathrm{~mol} \%$. The habitat is a freshwater hydrothermal source in the Uzon caldera on the Kamchatka peninsula, Russia.

The type strain is Z-9801 ${ }^{\mathrm{T}}$ (= DSM $14006^{\mathrm{T}}$ ), which has also been deposited in the Unique Micro-organism Classification and Storage Laboratory of the Institute of Microbiology, Russian Academy of Sciences, under the accession number UNIQEM $210^{\mathrm{T}}$.

\section{ACKNOWLEDGEMENTS}

This work was supported in part by grant 99-05-65267 from the Russian Foundation for Basic Research, by the Federal Programme 'Biodiversity' of the Ministry of Science and Technology, Russian Federation, and by grant no. 196 to young scientists of the Russian Academy of Sciences. We thank N. A. Chernyh for determination of the $\mathrm{G}+\mathrm{C}$ content of DNA and N. A. Kostrikina for electron microscopy.

\section{REFERENCES}

Balashova, V. V. \& Zavarzin, G. A. (1980). Anaerobic reduction of ferric iron by hydrogen bacteria. Microbiology (English translation of Mikrobiologiya) 48, 635-639.

Bonch-Osmolovskaya, E. A., Sokolova, T. G., Kostrikina, N. A. \& Zavarzin, G. A. (1990). Desulfurella acetivorans gen. nov. and sp. nov. - a new thermophilic sulfur-reducing eubacterium. Arch Microbiol 153, 151-155.

Boone, D. R., Liu, Y., Zhao, Z.-J., Balkwill, D. L., Drake, G. R., Stevens, T. O. \& Aldrich, H. C. (1995). Bacillus infernus sp. nov., an $\mathrm{Fe}(\mathrm{III})$ - and $\mathrm{Mn}(\mathrm{IV})$-reducing anaerobe from the deep terrestrial subsurface. Int J Syst Bacteriol 45, 441-448.

Collins, M. D., Lawson, P. A., Willems, A., Cordoba, J. J., Fernandez-Garayzabal, J., Garcia, P., Cai, J., Hippe, H. \& Farrow, J. A. E. (1994). The phylogeny of the genus Clostridium: proposal of five new genera and eleven new species combinations. Int $J$ Syst Bacteriol 44, 812-826.

Felsenstein, J. (1989). PHYLIP, Phylogenetic inference package (version 3.2). Cladistics 5, 164-166.

Greene, A. C., Patel, B. K. C. \& Sheehy, A. J. (1997). Deferribacter thermophilus gen. nov., sp. nov., a novel thermophilic manganese- and iron-reducing bacterium isolated from a petroleum reservoir. Int J Syst Bacteriol 47, 505-509.

Hattori, S., Kamagata, Y., Hanada, S. \& Shoun, H. (2000). Thermacetogenium phaeum gen. nov., sp. nov., a strictly anaerobic, thermophilic, syntrophic acetate-oxidizing bacterium. Int J Syst Evol Microbiol 50, 1601-1609.

Higgins, D. G. \& Sharp, P. M. (1988). CluSTAL: a package for performing multiple sequence alignment on a microcomputer. Gene $\mathbf{7 3}$, 237-244.

Hungate, R. E. (1969). A roll tube method for cultivation of strict anaerobes. Methods Microbiol 3B, 117-132.

Jukes, T. H. \& Cantor, C. R. (1969). Evolution of protein molecules. In Mammalian Protein Metabolism, pp. 21-132. Edited by H. N. Munro. New York: Academic Press.

Kieft, T. L., Fredrickson, J. K., Onstott, T. C. \& 8 other authors (1999). Dissimilatory reduction of Fe(III) and other electron acceptors by a Thermus isolate. Appl Environ Microbiol 65, 1214-1221.

Lee, Y.-E., Jain, M. K., Lee, C., Lowe, S. E. \& Zeikus, J. G. (1993). Taxonomic distinction of saccharolytic anaerobes: description of Thermoanaerobacterium xylanolyticum gen. nov., sp. nov., and Thermoanaerobacterium saccharolyticum gen. nov., sp. nov.; reclassification of Thermoanaerobium brockii, Clostridium thermosulfurogenes, and
Clostridium thermohydrosulfuricum E100-69 as Thermoanaerobacter brockii comb. nov., Thermoanaerobacterium thermosulfurigenes comb. nov., and Thermoanaerobacter thermohydrosulfuricus comb. nov., respectively; and transfer of Clostridium thermohydrosulfuricum 39E to Thermoanaerobacter ethanolicus. Int J Syst Bacteriol 43, 41-51.

Lovley, D. R. (1991). Dissimilatory Fe(III) and Mn(IV) reduction. Microbiol Rev 55, 259-287.

Lovley, D. R. (1995). Microbial reduction of iron, manganese, and other metals. Adv Agron 54, 175-231.

Lovley, D. R. \& Phillips, E. J. P. (1988). Novel mode of microbial energy metabolism: organic carbon oxidation coupled to dissimilatory reduction of iron and manganese. Appl Environ Microbiol 54, 1472-1480

Lowe, S. E., Jain, M. K. \& Zeikus, J. G. (1993). Biology, ecology, and biotechnological applications of anaerobic bacteria adapted to environmental stresses in temperature, $\mathrm{pH}$, salinity, or substrates. Microbiol Rev 57, 451-509.

Maidak, B. L., Cole, J. R., Lilburn, T. G. \& 9 other authors (2000). The RDP (Ribosomal Database Project) continues. Nucleic Acids Res 28, 173-174.

Marmur, J. (1961). A procedure for the isolation of desoxyribonucleic acid from microorganisms. J Mol Biol 3, 208-218.

Marmur, J. \& Doty, P. (1962). Determination of the base composition of deoxyribonucleic acid from microorganisms. J Mol Biol 5, 109-118.

Nealson, K. H. \& Saffarini, D. (1994). Iron and manganese in anaerobic respiration: environmental significance, physiology, and regulation. Annu Rev Microbiol 48, 311-343.

Pfennig, N. \& Wagner, S. (1986). An improved method of preparing wet mounts for photomicrographs of microorganisms. J Microbiol Methods 4, 303-306.

Pikuta, E., Lysenko, A., Chuvilskaya, N., Mendrock, U., Hippe, H., Suzina, N., Nikitin, D., Osipov, G. \& Laurinavichius, K. (2000). Anoxybacillus pushchinensis gen. nov., sp. nov., a novel anaerobic, alkaliphilic, moderately thermophilic bacterium from manure, and description of Anoxybacillus flavithermus comb. nov. Int $J$ Syst Evol Microbiol 50, 2109-2117.

Rainey, F. A., Ward, N. L., Morgan, H. W., Toalster, R. \& Stackebrandt, E. (1993). Phylogenetic analysis of anaerobic thermophilic bacteria: aid for their reclassification. J Bacteriol 175, 4772-4779.

Slobodkin, A. I. \& Bonch-Osmolovskaya, E. A. (1994). Growth and formation of metabolic products by extremely thermophilic archaea of the genus Desulfurococcus in the presence and absence of elemental sulfur. Microbiology (English translation of Mikrobiologiya) 63, 552-554.

Slobodkin, A., Reysenbach, A.-L., Strutz, N., Dreier, M. \& Wiegel, J. (1997). Thermoterrabacterium ferrireducens gen. nov., sp. nov., a thermophilic anaerobic dissimilatory $\mathrm{Fe}$ (III)-reducing bacterium from a continental hot spring. Int J Syst Bacteriol 47, 541-547.

Slobodkin, A. I., Zavarzina, D. G., Sokolova, T. G. \& BonchOsmolovskaya, E. A. (1999a). Dissimilatory reduction of inorganic electron acceptors by thermophilic anaerobic prokaryotes. A review. Microbiology (English translation of Mikrobiologiya) 68, 522-543.

Slobodkin, A. I., Tourova, T. P., Kuznetsov, B. B., Kostrikina, N. A., Chernyh, N. A. \& Bonch-Osmolovskaya, E. A. (1999b). Thermoanaerobacter siderophilus sp. nov., a novel dissimilatory $\mathrm{Fe}(\mathrm{III})-$ reducing, anaerobic, thermophilic bacterium. Int J Syst Bacteriol 49, 1471-1478

Slobodkin, A. I., Jeanthon, C., L'Haridon, S., Nazina, T., Miroshnichenko, M. \& Bonch-Osmolovskaya, E. (1999c). Dissimilatory reduction of $\mathrm{Fe}$ (III) by thermophilic bacteria and archaea in deep subsurface petroleum reservoirs of Western Siberia. Curr Microbiol 39, 99-102

Straub, K. L., Benz, M. \& Schink, B. (2001). Iron metabolism in anoxic environments at near neutral pH. FEMS Microbiol Ecol 34, 181-186.

Strimmer, K. \& von Haeseler, A. (1996). Quartet puzzling: a quartet maximum likelihood method for reconstructing tree topologies. $\mathrm{Mol}$ Biol Evol 13, 964-969.

Van de Peer, Y. \& De Wachter, R. (1994). TREECON for Windows: a 
software package for the construction and drawing of evolutionary trees for the Microsoft Windows environment. Comput Appl Biosci 10, 569-570.

Vargas, M., Kashefi, K., Blunt-Harris, E. L. \& Lovley, D. R. (1998). Microbiological evidence for Fe(III) reduction on early Earth. Nature 395, 65-67.

Wiegel, J. K. W. (1986). Genus Thermoanaerobacter Wiegel and Ljungdahl 1982. In Bergey's Manual of Systematic Bacteriology, vol. 2, pp. 1379-1383. Edited by P. H. A. Sneath, N. S. Mair, M. E. Sharpe \& J. G. Holt. Baltimore: Williams \& Wilkins.

Woese, C. R., Achenbach, L., Rouviere, P. \& Mandelco, L. (1991). Archaeal phylogeny: reexamination of the phylogenetic position of Archaeoglobus fulgidus in light of certain composition-induced artifacts. Syst Appl Microbiol 14, 364-371.

Wolin, E. A., Wolin, M. J. \& Wolfe, R. S. (1963). Formation of methane by bacterial extracts. J Biol Chem 238, 2882-2886. 